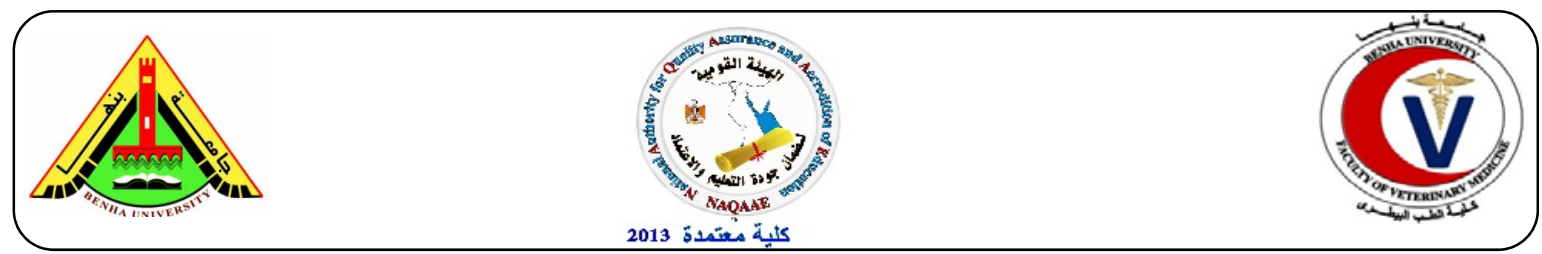

\title{
Bacteriological and immunological studies on some bacterial pathogens incriminated in bovine Mastitis.
}

\author{
Ashraf A. Abdel-Tawab ${ }^{1}$, Ahmed A.A. Maarouf ${ }^{2}$, Fatma I. El-Hofy ${ }^{1}$, Sameh A.H. Abbas ${ }^{3}$ \\ ${ }^{1}$ Department of Bacteriology, Immunology and Mycology, Faculty of Veterinary Medicine, Benha \\ University. ${ }^{2}$ Animal Health Research Institute, Benha Branch. ${ }^{3}$ Kaluobia Vet. Med. Organization, El- \\ Kanater El-Khayria.
}

\section{A B S T R A C T}

In this study a total of 1200 quarter milk samples were selected from 300 cows from different localities at El-Kaluobia governorate. The bacteriological examination revealed that a total of 125 isolates from clinical and subclinical mastitic milk samples of which 57 S.aureus isolates were isolated from both mastitic milk .with incidence of $45.6 \%$ of total isolates, 28 E.coli with $22.4 \%, 13$ S.agalactia with $10.4 \%$, 9 S. dysgalactia with $7.2 \%, 7$ isolates of both S.uberis \& coagulase negative staph (5.6\%), 3 Klebsiella $s p$ with $2.4 \%$ and 1 Pseudomonas sp with $0.8 \%$. Mean titer of anti $S$ aureus specific IgA was higher in milk of subclinical mastitic cases (1:845) than clinical one(1:290), while mean titer in milk of clinical and subclinical mastitic cases much higher than in serum of clinical(1:54)and subclinical (1:41), while mean titer of anti S. aureus specific IgM and IgG was much higher in serum of clinical(1:1382, 1:868 for IgM\&1:1267 , 1:634 for IgG ) than milk of clinical and subclinical mastitic cases $(1: 111,1: 53$ for IgM \& 1: $302,1: 206$ for IgG). Results of sensitivity tests of S.aureus against different antibiotic discs revealed that $93 \%, 91.2 \%, 87.2 \%$ and $63.2 \%$, were sensitive to Amoxicillin /Clavulanic acid, Gentamycin, Cloxacillin, Sulphamethoxazole /Trimethoprim while $87.7 \%, 86.0 \%, 84.2 \%$ and $82.5 \%$ of isolates were resistant to Nalidixic acid, Streptomycin, Oxytetracycline and Penicillin-G.

Keywords: Mastitis, Cattle, Immunoglobulins, Antibacterial.

(http://www.bvmj.bu.edu.eg) $\quad$ (BVMJ-30(1): 118-123, 2016)

\section{INTRODUCTION}

$\mathrm{M}$ astitis is one of the most common diseases affecting dairy Cows. It is defined as inflammation of mammary gland accompanied with physical, chemical, microbiological and cellular changes in the milk as well as pathological changes in the udder (Merck veterinary manual, 2006). The severity of inflammation depends on the causative agents and the host response (Petzl et al., 2008). It is important to note that $S$. aureus is considered as the main contagious udder bacteria causing clinical and sub clinical mastitis. It impairs the alveolar function, reduces milk yield and has a deleterious effect on milk composition and increase the milk somatic cell count
(Leitner et al., 2000), the pathological effect of $S$. aureus infection is formation of abscesses in deep tissue and become foci for bacterial shedding in chronically infected animals and the diseased Cow become high refractory to antibiotic therapy (Alluwaimi et al., 2003).Economic losses due to mastitis have been established worldwide as $\$ 35$ billion (Wellenberg et al., 2002).Mastitis can be diagnose by physical methods such as redness, hotness, swelling of udder and painful on palpation, also CMT(Cow side test)and SCC test .So the aim of this work was to determine the Prevalence of mastitis with its two main forms(clinical and subclinical). Application of the traditional methods of isolation and identification for 
common bacteria causing mastitis in clinically diseased and apparently healthy dairy cows with special regards to $S$. aureus, also studying the correlation between type of mastitis and the production of specific $\operatorname{IgA}, \operatorname{IgM}$ and IgG antibodies in blood and milk beside studying antibiotics sensitivity test to choose the most effective antibiotic against $S$. aureus mastitis.

\section{MATERIAL AND METHODS}

\subsection{Milk collection}

A total 1200 individual quarter milk samples were collected from 300 Cows from different localities at El-Kaluobia Governorate according to National Mastitis Council (1990). By using CMT 1060 quarter milk samples were apparently normal (from 265 Cows) while the remaining 140 quarter milk samples were taken from 35 Cows showing clinical mastitis also 50 blood samples were taken from normal and mastitic cases for immunological examination.

\subsection{Bacteriological examination}

A loopful of each quarter milk sample streaked into nutrient agar, blood agar, MacConKey's agar, Mannitol salt agar, Baired parker agar, eosin methylene blue agar(EMB)and Pseudomonas agar as described by Quinn et al., 2002.All plates were incubated for 24 hours at $37^{\circ} \mathrm{C}$. The developed colonies were picked up\&sub culturing for purification of the isolates. The purified colonies were subjected for morphological identification by Gram stain \&biochemical tests.

\subsection{Immunological assay (Leitner et al., 2000)}

Serum and milk whey samples were examined by enzyme linked immunosorbent assay (ELISA) for determination of immunological changes occurred to the immunoglobulins (IgA, IgM and $\mathrm{IgG}$ ) in case of clinical and sub clinical mastitis as described.

\subsection{Antibiotic sensitivity test by Leitner et al., 2000 for the isolated S. aureus}

In-Vitro sensitivity test was done for isolated S. aureus strain (57 isolates) to study its antibiotic Sensitivity. The disc diffusion technique was applied according to (CLSI, 2011). The used discs were Amoxicillin Clavulanic acid 20-10ug, Cloxacillin25ug, Oxytetracycline 30ug, Gentamycin 10ug, Erythromycin15ug, Trimethoprim- Sulphamethoxazole1 25$23.75 \mathrm{mcg}$, Penicillin-G 10IU, Ampicillin $10 \mathrm{mcg}$, Streptomycin 10ug and Nalidixic acid $30 \mathrm{mcg}$.

\section{RESULTS}

\subsection{Prevalence of clinical and sub clinical mastitis using CMT}

Examination of the healthy state of the mammary glands of 300 Cows revealed that 35 Cows clinically mastitis with prevalence of $11.66 \%$, while the other remaining Cows 265 were apparently normal with prevalence of $88.33 \%$ Examination of quarter milk samples of the Cows by CMT showed that the incidence of subclinical mastitic Cows among the apparently normal Cows were 80 with prevalence of $26.66 \%$, while the clinically mastitic were 35.The total number of mastitic Cows were 115 out of 300 Cows with an incidence of $38.33 \%$ as shown in (table I).

\subsection{Results of bacteriological examination}

Bacteriological examination of 38 clinically mastitic quarter milk samples , 140 subclinically mastitic quarter milk samples revealed single and mixed infection in the clinically mastitic quarter milk samples with prevalence of $77.1 \%$ and $22.9 \%$ respectively, while single and mixed infection of the subclinically mastitic quarter milk samples with prevalence of $90.8 \%$ and $9.2 \%$ respectively, while 64 quarter milk samples of the subclinical mastitic samples were negative for bacterial isolation with prevalence of $45.7 \%$ (Table2). It is clear that the total number of 
isolates were 125. From the clinical mastitic cases 43 bacterial isolates with prevalence of $34.4 \%$ meanwhile 82 isolates from sub clinical mastitis cases with prevalence of $65.6 \%$. The predominant bacterial species isolated were as follow, S.aureus 57 isolates with incidence of $45.6 \%$, E.coli 28 with prevalence of $22.4 \%$, S. agalactia 13 with prevalence of $10.4 \%$, S.dysgalactia 9 with prevalence of $7.2 \%$, S.uberis 7 with prevalence of $5.6 \%$, CNS 7 with prevalence of $5.6 \%$, Klebsiella spp 3 with prevalence of $2.4 \% P$. aeroginosa 1 with prevalence of $0.8 \%$ (Table 3 ).

\subsection{Results of immunological assay}

The results of ELISA showed that:

The high mean titer of anti S.aureus specific IgA was found in sub clinical mastitis milk than clinical ones (Table 4).
Also the high mean titer of anti S.aureus specific IgM was found in clinical mastitis milk and serum than sub clinical ones (Table 5). More over the high mean titer of anti S.aureus $\mathrm{IgG}$ was found in clinical mastitis milk and serum than sub clinical ones (Table 6).

\subsection{Result of antimicrobial sensitivity}

The in- vitro sensitivity tests of S.aureus Table (7) showed that, the isolated S.aureus was highly sensitive to AmoxicillinClavulanic acid (93\%), Gentamycin (91.2\%). Cloxacillin (87.2\%), meanwhile they were resistant to Nalidixic acid (87.7\%), Streptomycin $\quad(86.0 \%)$ and Oxytetracycline (84.2\%).

Table (1) Prevalence of mastitis using the California mastitis test (CMT)

\begin{tabular}{|c|c|c|c|c|c|c|c|c|}
\hline \multirow{2}{*}{$\begin{array}{l}\text { No. of } \\
\text { Cows }\end{array}$} & \multicolumn{2}{|c|}{$\begin{array}{c}\text { Clinical mastitic } \\
\text { cases }\end{array}$} & \multicolumn{2}{|c|}{$\begin{array}{c}\text { Subclinical mastitic } \\
\text { cases }\end{array}$} & \multicolumn{2}{|c|}{$\begin{array}{c}\text { Total } \\
\text { mastitic cases }\end{array}$} & \multicolumn{2}{|c|}{ Healthy Cows } \\
\hline & No. & $\%$ & No. & $\%$ & No. & $\%$ & No. & $\%$ \\
\hline 300 & 35 & 11.7 & 80 & 26.7 & 115 & 38.3 & 185 & 61.7 \\
\hline
\end{tabular}

Table (2) Incidence of bacteria (single \& mixed) recovered from examined quarter milk samples

\begin{tabular}{|c|c|c|c|c|c|c|c|c|c|}
\hline \multirow{3}{*}{ Health state of Cows } & \multirow{3}{*}{$\begin{array}{l}\text { Number } \\
\text { of } \\
\text { examined } \\
\text { quarters }\end{array}$} & \multicolumn{6}{|c|}{ Results of bacterial examination } & \multirow{2}{*}{\multicolumn{2}{|c|}{$\begin{array}{c}\text { Total } \\
\text { infected } \\
\text { cases }\end{array}$}} \\
\hline & & \multicolumn{2}{|c|}{ Negative } & \multicolumn{2}{|c|}{$\begin{array}{c}\text { Single } \\
\text { infection }\end{array}$} & \multicolumn{2}{|c|}{$\begin{array}{l}\text { Mixed } \\
\text { infection }\end{array}$} & & \\
\hline & & No. & $\%$ & No. & $\%$ & No. & $\%$ & No. & $\%$ \\
\hline Clinically & 38 & 3 & 7.9 & 27 & 77.1 & 8 & 22.9 & 35 & 92.1 \\
\hline $\begin{array}{l}\text { Positive CMT quarters } \\
\text { (subclinical mastiticCow) }\end{array}$ & 140 & 64 & 45.7 & 69 & 90.8 & 7 & 9.2 & 76 & 54.3 \\
\hline Total & 178 & 67 & 37.6 & 96 & 86.5 & 15 & 13.5 & 111 & 62.4 \\
\hline
\end{tabular}

Table (3) Prevalence of different bacterial isolates recovered from examined quarter milk sample

\begin{tabular}{lcccccc}
\hline \multirow{2}{*}{ Bacterial isolates } & \multicolumn{2}{c}{ Clinical mastitis (35) } & \multicolumn{2}{c}{ Positive CMT (76) } & \multicolumn{2}{c}{ Total (111) } \\
\cline { 2 - 7 } & No. & $\%$ & No. & $\%$ & No. & $\%$ \\
\hline S.aureus & 21 & 48.8 & 36 & 43.9 & 57 & 45.6 \\
E.coli & 8 & 18.6 & 20 & 24.4 & 28 & 22.4 \\
S. agalactia & 3 & 7.0 & 10 & 12.2 & 13 & 10.4 \\
S. dysgalactia & 4 & 9.3 & 5 & 6.1 & 9 & 7.2 \\
S. uberis & 3 & 7.0 & 4 & 4.9 & 7 & 5.6 \\
Klebsiella sp. & 1 & 2.3 & 2 & 2.4 & 3 & 2.4 \\
P. aeruginosa & -- & -- & 1 & 1.2 & 1 & 0.8 \\
CNS & 3 & 7.0 & 4 & 4.9 & 7 & 5.6 \\
Total & 43 & 100 & 82 & 100 & 125 & 100 \\
\hline
\end{tabular}


Table (4) Effect of type of mastitis on anti S. aureus specific IgA in milk whey and serum

\begin{tabular}{cccc}
\hline & -ve CMT samples & Clinical mastitis samples & Sub clinical mastitis \\
\cline { 2 - 4 } Milk & 31 & 290 & 845 \\
serum & 20 & 54 & 41 \\
\hline
\end{tabular}

Table (5) Effect of type of mastitis on anti S. aureus specific IgM in milk whey and serum

\begin{tabular}{cccc}
\hline & -ve CMT samples & Clinical mastitis samples & Sub clinical mastitis \\
\cline { 2 - 4 } Milk & 16 & 111 & 53 \\
serum & 161 & 1382 & 868 \\
\hline
\end{tabular}

Table (6) Effect of type of mastitis on anti S. aureus specific IgG in milk whey and serum

\begin{tabular}{cccc}
\hline & -ve CMT samples & Clinical mastitis samples & Sub clinical mastitis \\
\cline { 2 - 4 } Milk & 61 & 302 & 206 \\
serum & 103 & 1267 & 634 \\
\hline
\end{tabular}

Table (7) In-vitro anti-microbial sensitivity test of isolated S. aureus

\begin{tabular}{lccc}
\hline Antibiotics & highly sensitive & intermediate sensitive & Resistant \\
\hline Amoxicillin/Clavulanic acid & 93 & 1.7 & 5.3 \\
Gentamycin & 91.2 & 1.8 & 7.0 \\
Cloxacillin & 87.2 & 3.3 & 9.5 \\
Trimethoprim/ Sulphamethoxazole & 63.2 & 7.5 & 29.3 \\
Ampicillin & 38.6 & 10.5 & 50.9 \\
Erythromycin & 31.6 & 19.3 & 49.1 \\
Penicillin G & 12 & 5.5 & 82.5 \\
Oxytetracycline & 11 & 4.8 & 84.2 \\
Streptomycin & 10.5 & 3.5 & 86.0 \\
Nalidixic acid & 9.1 & 3.2 & 87.7 \\
\hline
\end{tabular}

\section{DISCUSSION}

The prevalence of subclinical mastitis was higher than clinical mastitis where it was $26.7 \%$. This result was correlate with that of El-Sayed, (2009)27.45\%, but disagree with that reported by Karimuribo et al, (2008) $75.9 \%$. Concerning bacteriological examination a total number of (178) quarter milk sample (QMS) collected from (140) QMS of subclinical cases and (38) QMS of clinical mastitis were examined Bacteriologically and as shown in table (1), it revealed that 111 QMS (62.4\%) were
Bacteriologically positive while 67 QMS $(37.6 \%)$ were negative .In this respect lower results were reported by El-seedy et al., (2010) who found that the bacteriologically positive QMS was $44.3 \%$ and higher estimates was recorded by Lakew et al., (2009) who concluded that bacteriologically positive QMS was $92.36 \%$. more over single and mixed infection were detected in $(77.1 \%)$ and $(22.9 \%)$ respectively. while in subclinically mastitic the mixed infection was $(9.2 \%)$ only while single infection was $(90.8 \%)$ as in table (1), also $64(45.7 \%)$ samples were culturally negative among subclinical 
mastitis quarters. As shown in table (2) S.aureus was the predominant bacteria $45.6 \%$ of total isolates. Nearly rephrase results were recorded by Parmar, et al., (2006) who found that $34 \%$ from subclinical mastitic cases caused by S.aureus, however these results were lowered than that observed by Risvanl and Kalkan, (2002) who reported 51.4\%. these results were nearly similar to that obtained by EL -Seedy et al., (2010) who reported that bacteriologically positive QMS was $44.3 \%$, but it was differed with results of Lakew et al., (2009) who reported that bacteriologically positive samples was $92.36 \%$. Concerning the results of S.aureus mastitis in clinical cases these results were $48.8 \%$ and in subclinical mastitis was $43.9 \%$. These results were nearly agreed with that of Miranda -Morales et al (2008) $30 \%$ while it was slightly higher than that obtained by Dubal et al., (2010) 42.14\%. In the same time, the results were much higher than that reported by Nam et al., (2010) who found that $S$.aureus isolated at percentage of $12.2 \%$. Referring to antibiotic and sensitivity a total number of (57) S. aureus strains isolated from clinical and subclinical mastitic cases were subjected to antibiotic sensitivity tests against different antibiotics. The results showed that S.aureus was highly sensitive to Amoxicillin / Clavulanic acid $(93 \%)$ but resist Nalidixic acid $(87.7 \%)$, Streptomycin $(86.0 \%)$.These results were mostly agreed with that reported by El Sayed, (2010) who found that S.aureus sensitive to Amoxicillin / Clavulanic acid by $89.2 \%$ and El-Seedy et al., (2010) who found that the examined S.aureus isolates in Cows were sensitive to Gentamycin (90.6\%) and Amoxicillin / Clavulanic acid $(84.9 \%)$ while resistant to Penicillin (64.2\%) .In this respect Andrade et al., (2001) revealed that $90.72 \%$ of S.aureus was sensitive to Gentamycin. Ayman et al., (2012) mentioned that Penicillin resistance wasof $85.7 \%$ Also Ikiz et al., (2013) who reported that Gentamycin sensitivity was $(91.66 \%)$, Streptomycin resistance was $(83.4 \%)$. Concerning the effect of mastitis type on immunoglobulins level and as in table (4) there was a higher mean titer of anti S.aureus specific IgA in subclinical mastitic milk than that of clinical and normal milk samples. These results were in agreement with that reported by Leitner et al., (2000) who reported that IgA antibody was the major immunoglobulin isotype in most of the infected quarters with subclinical chronic mastitis but not in non-infected ones. Table (5) showed that there was a higher mean titer of anti S.aureus specific IgM in clinically mastitic milk and in serum than that of subclinical cases, also the level in subclinical milk was higher than normal milk samples. Table (6) illustrated higher mean titer of anti S.aureus specific IgG in clinical mastitic milk and serum than that of subclinical mastitic milk and serum. The mean titer in subclinical mastitic cases was higher than that recorded in normal milk samples and the mean titer of anti S.aureus specific IgG in sera was higher than that in milk ones. These results were in agreement with that reported by Leitner et al., (2000).

\section{REFERENCES}

Andrade, M.A., Dias Filho, F.D.E.C., Mesquita, A.J.D.E., Rocha, P.T. 2001. In vitro sensitivity test of staphylococcus aureus isolated from milk samples from cattle with sub clinical mastitis. Ciecia Anim. Brazil, 1(1): 53 - 57.

Alluwaimi, A.M., Leutenegger, C.M., Farver, T.B., Rossito, P.V., Smith, W.L., Cullor, J.S. 2003. The cytokine markers in Staphylococcus aureus mastitis of bovine mammary gland. J. Vet Med. B infect. Dis. Vet. Public Health. 50 (3): 105-111.

Ayman, El-Behiry, GerdSchlenker, IstvanSzabo, UweRoesler. 2012. In vitro susceptibility of Staphylococcus aureus strains isolated from cows with sub clinical mastitis to different antimicrobial agents J. Vet. Sci.; 13 (2), 153-161.

Clinical and laboratory standards institute (CLSI) 2011.Performance standards for antimicrobial susceptibility testing, twenty - seconds' informational supplement M 100-S22. 
Dubal, Z.B., Rahman, H., Papri Pal, Kumar, A., KalpanaPradhan. 2010. Characterization and antimicrobial sensitivity of the pathogens isolated from bovine mastitis with special reference to Escherichia coli and Staphylococcus Spp. Indian journal of animal Science; 80(12): 1163 -1167.

El - Sayed, Z.S. 2009. Some studies on bovine mastitis with special references to its control Ph.D. thesis Fac. Vet. med. Mansoura Univ.

El-Sayed, SaharAbd El-Naby. 2010. Studies on Staphylococcus bovine mastitis. Master thesis, Fac. vet. Med. Benha Univ., Egypt.

El-Seedy, F.R., EL-Shabrawy, M., Hakim, A.S., Dorgham, S.M., Ata, S., Nagwa, Bakry, M.A., Osman, N.M.N. 2010. Recent Techniques used for Isolation and characterization of Staphylococcus aureus from mastitis cows Journal of American Science, 6 (12) :540-547

Ikiz, Serkan, Beren Basaran, Enver Baris BINGOL, Omer Cetin, Guven KASIKCI, Naciye Yakut OZGUR, Melih UCMAK, Ozge YILMAZ, Mehmet Can GUNDUZ, Ahmet SABUNCU 2013.Presence and antibiotic susceptibility patterns of contagious mastitis agents (Staphylococcus aureus and Streptococcus agalactia) isolated from milk of dairy cows with subclinical mastitis. Turk J Vet Anim Sci.; 37:569 574.

Karimuribo, E.D., Fitzpatrick, J.L., Swai, E.S., Bell, C., Bryant, M.J., Ogden, N.H., Kambarage, D.M., French, N.P. 2008. Prevalence of sub clinical mastitis and associated risk factors in smallholder dairy cows in Tanzania. Vet Res., 163: 16 -21 .

Lakew, M., Tolosa, T., Tigre, W. 2009. Prevalence and major bacterial causes of bovine mastitis in Asella, South Eastern Ethiopia. Trop. Anim. Health Prod.45:180-185.

Leitner, G., Yadlin, B., Glickman, A., Chaffer, M.N.D., Saran, L. 2000. Systematic and local immune response of Cows to intramammary infection with Staphylococcus aureus. Res Vet Sci. Oct; 69 (2): 181184.

Merck Veterinary Manual 2006. http:// www.merck vet manual.com .htm.
Miranda-Morales, R.E., Rojas-Trejo, V., Segura-Candelas, R., Carrillo-Casas, E.M., Sanchez-Gonzalez, M.G., Castor, R.S., trigoTavera, F.J. 2008. Prevalence of pathogens associated with bovine mastitis in bulk tank milk in Mexico. Ann. N.Y. Acad. Sci.; 1149: 300 - 302.

Nam, H.M., Kim, Lim, S.K., Jang, K.C., Jung, S.C. 2010. Infectious etiologies of mastitis on Korean dairy farms. Res. Vet. Sci. 12:321-324.

National Mastitis Council 1999. Microbiological procedures for the diagnosis of bovine udder infection, National Mastitis Council . $3^{\text {rd }}$ ed. Arlington, Virginia, USA.

Parmar, D., Rastogi, S.K.., Mathur, N., Seth, P.K.., Dahawan, A. 2006. DNA damage in lymphocytes of Indian rickshaw pullers as measured by the alkaline comet assay. Environ Mol Mutagen. 47(1):2530.

Petzl, W., Zerbe, H., Gunther, J., Yang, W., Seyfert, H.M., Nurnberg, G., Schuberth, H.J. 2008. Escherichia coli, but not Staphylococcus aureus triggers an early increased expression of factors contributing to the innate immune defense in the udder of the cow. Veterinary Research 39(2):18.

Quinn, P.J., Markey, B.K.., Carter, M.E., Donnell, W.J.C., Leonard, F.C. .2002. "Veterinary Microbiology and Microbial Diseases " Blackwell Science, London, UK. Rocz. Panstu. Zaki. Hig., 41(56):263-268.

Risvanl, S.J., Kalkan, F.W.Q. 2002. Multifactorial relationships between intra-mammary invasion by Staphylococcus aureus and bovine leucocytes markers Can J Vet Res. Apr; 71(2): 135-44.

Wellenberg, G.J., VanDerPoel, W.H.M., Van Oirschot, J.T. 2002.Viral infections and bovine mastitis: a review. Vet. Microbiol, $88: 27-45$. 